\title{
1 Should I plant or should I sow? Restoration outcomes compared across seven
}

\section{2 riparian revegetation projects}

3 Joe Greet, Fiona Ede, Dan Robertson and Scott McKendrick

4 Joe Greet, Fiona Ede and Scott McKendrick are Research Fellows and a Research Assistant,

5 respectively, with the School of Ecosystem and Forest Sciences, The University of Melbourne,

6 (Burnley VIC, 3121, Australia, Email: greetj@unimelb.edu.au). Dan Robertson is a Waterways and

7 Land Officer with Melbourne Water (990 La Trobe St, Docklands VIC 3008, Email:

8 Dan.Robertson@melbournewater.com.au).This project arose from research into revegetation

9 outcomes to inform improvement of revegetation practices along riparian areas by Melbourne

10 Water.

Acknowledgements

13 We would like to acknowledge the assistance of Melbourne Water staff in providing access to sites

14 and details of management of the revegetation projects. We also thank Gen Hehir, Rob Dabal, Fern

15 Yong, Sarah Fischer, Harry Coleman, Jasmine Thom and Tony Lovell for their help with field surveys.

16 This research was funded by Melbourne Water through the Melbourne Waterways Research

17 Practice Partnership.

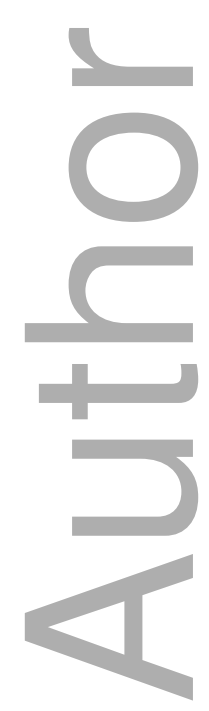

This is the author manuscript accepted for publication and has undergone full peer review but has not been through the copyediting, typesetting, pagination and proofreading process, which may lead to differences between this version and the Version of Record. Please cite this article as doi: $10.1111 /$ emr.12396

This article is protected by copyright. All rights reserved 
3

4

Article type : Technical report

6

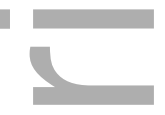

8 Should I plant or should I sow? Restoration outcomes compared across seven

9 riparian revegetation projects

Summary

To revegetate native plant communities, it is often cheaper to direct seed than to plant nursery grown stock. However, the outcomes of direct seeding can be quite variable, and it is unclear whether direct seeding or planting is more likely to facilitate the restoration of diverse plant communities. To address this question, we compared the outcomes of each method across several recent riparian revegetation projects where both direct seeding and tube-stock planting were used.

We surveyed riparian revegetation projects at seven sites within the greater Melbourne area that had been revegetated between 1 and 4 years previously. Sites were all on land previously used for agriculture or degraded public land and ranged in environmental and climatic conditions. Woody plant density, establishment of target species, species richness, species diversity (evenness) and plant heights were assessed.

Direct seeding tended to result in higher plant densities, similar species richness, but lower rates of species establishment and diversity compared with planting, A median of $67 \%$ of target species established via direct seeding compared with $100 \%$ for planting, with direct seeded areas often dominated by one or two species. In general, overall revegetation outcomes were often driven by climatic and site factors, rather than revegetation method. We suggest that to achieve good restoration outcomes from revegetation in riparian areas, a bet-hedging or combined approach using both sowing and planting may be the best strategy.

This article is protected by copyright. All rights reserved 


\section{Keywords (5-10 words)}

Biodiversity, direct seeding, ecological restoration, riparian revegetation, tube-stock planting, vegetation diversity.

\section{ren}

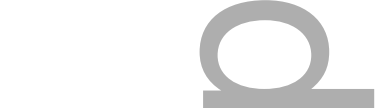

\section{Introduction}

"Ecological restoration is the process of assisting the recovery of an ecosystem that has been degraded, damaged or destroyed", with the goal to create a self-supporting ecosystem that is resilient to perturbation (SER 2004). Restoration actions that enhance biodiversity should support enhanced provision of ecosystem services and resilience (Benayas et al. 2009).

Revegetation is often desirable to accelerate ecosystem recovery and is the most common approach to restoring plant communities (Palma and Laurance 2015; Ruiz-Jaen and Mitchell Aide 2005). Active revegetation involves either direct seeding or planting of nursery-grown stock. While direct seeding is typically cheaper than planting (Atondo-Bueno et al. 2018; Cole et al. 2011; Ede et al. 2017; Pérez et al. 2019), direct seeding outcomes can be quite variable (Ammondt et al. 2013; Ruthrof et al. 2010). Moreover, the comparative diversity outcomes of the two approaches are not well understood.

Evaluation of revegetation effectiveness is often poorly done, if done at all, with poor recordkeeping often making it difficult to assess outcomes (Brooks and Lake 2007). Where revegetation outcomes are assessed, success is often evaluated in terms of parameters reflecting vegetation structure, which require less expert knowledge and are more readily measurable compared to vegetation diversity or ecosystem processes (Ruiz-Jaen and Mitchell Aide 2005).

There is a key knowledge gap in understanding how vegetation communities develop after revegetation and whether the method of revegetation influences vegetation diversity outcomes. We surveyed several revegetated sites where the objective of the revegetation was to enhance the riparian vegetation community by re-introducing appropriate native tree and shrub species. At each site, direct seeding and tube-stock planting had been undertaken and we asked which revegetation method resulted in better restoration outcomes. 
58

59

60

61

62

63

64

65

66

67

68

69

70

71

72

\section{Methods}

Study sites

Revegetation outcomes at seven riparian sites were assessed for this study. All sites were within the Greater Melbourne area and in a rural or peri-urban setting (Figure 1). The Emu Creek site had been revegetated across two years and each year's revegetation was considered separately. All sites had been revegetated $1-4$ years prior to survey and had been planted and sown with a mix of woody species selected to facilitate the establishment of the appropriate vegetation community for that site (Table 1).

The sites vary in their environmental characteristics such as soils and climate-e.g. four of the monitored sites are located within the fertile Yarra River valley, while two sites are located on the less fertile basalt plains west of Melbourne and experience a drier climate (Table 1). The adjacent land use also varied between sites, from the Yarra River site at McMahons Creek which is situated on the edge of the Yarra Ranges National Park to the Emu Creek site which is adjacent to a quarry (Table 1). At all sites, the original riparian vegetation had been cleared and at the time of revegetation, the vegetation at all sites was dominated by exotic species, primarily pasture grasses. Five sites were previously used for agricultural purposes, and two sites (Hoddles Creek and Cardinia Creek) were on degraded public lands. The extent to which factors such as fertiliser application, ploughing and compaction had compromised soil quality is unknown for most sites, and is not considered in our study.

\section{Revegetation activities}

Weed control was undertaken at all sites prior to revegetation and typically included at least two applications of a broad-spectrum herbicide to control herbaceous species (Table 1). In addition, mechanical slashing of tall herbaceous weeds such as grasses and thistles was undertaken prior to spraying at the Launching Place and Emu Creek sites. Woody weed control was also undertaken at these two sites with willows (Salix spp.) and African Boxthorn (Lycium ferocissimum) removed respectively.

Rabbit (Oryctolagus cuniculus) control measures were implemented at the Emu Creek and Deep Creek sites, but no other active herbivore control measures were employed at sites. At the McMahons Creek site, herbivore-exclusion fences were erected around all plots. All other sites were unfenced (Table 1).

This article is protected by copyright. All rights reserved 
While five sites were sown mechanically, two sites were sown by hand broadcasting (Table 1). Tubestock plants were planted by hand, into holes created by a mechanised augur, Hamilton planter or spade. Tree guards (plastic or wire mesh guards) were used at all unfenced sites except Hoddles Creek, and jute mats were placed at the base of plants at the time of planting at some sites (Table 1).

The seeding and planting rates, and the species mixes used at each site were based on the relevant vegetation community being restored. Some species were common to several sites, but no species was present at all sites. Within sites, similar species mixes were sown and planted, but different numbers of species were often present in the sowing and planting mixes, with more species generally sown than planted (Table 1 ).

Site maintenance after revegetation varied between sites (Table 1). Standard industry practice for post-establishment weed control was applied at most sites, with herbicide spraying around the base of tube-stock plants carried out up to three times per year after planting. For lines of direct seeding, spraying occurred between lines as close to the edge of the sown line as possible without risking damage to emerging seedlings. All site preparation, fencing, revegetation and site maintenance was carried out by contractors, following industry best practice.

\section{Data collection and synthesis}

Sampling protocols used at each site were flexible to account for differences in site size and characteristics. At the Cardinia Creek, Emu Creek sites and Hoddles Creek sites, all plants within sown and planted lines/plots were assessed. At the Deep Creek, Launching Place and Sheepstation Creek sites, randomly selected belt transects were used to sub-sample direct seeding lines. Transects encompassed sown lines and were either $20 \mathrm{~m}$ long (Sheepstation Creek) or $50 \mathrm{~m}$ long (remaining sites). The number of transects assessed per site varied with site size (minimum $n=6$ ). Low numbers of tube-stock were planted at the Deep Creek and Sheepstation Creek sites, and 50 plants were randomly sampled at these sites. At Launching Place, three randomly placed quadrats $(50 \mathrm{~m} \times 20 \mathrm{~m}$ ) were used to assess tube-stock plants. Similarly, at McMahons Creek, tube-stock were assessed in six $5 \mathrm{~m} \times 5 \mathrm{~m}$ quadrats, while twelve $1 \mathrm{~m} \times 1 \mathrm{~m}$ quadrats were used to assess the direct seeding at this site, with quadrats randomly placed. At all sites, the sampling intensity was sufficient to represent outcomes. In all cases, plant numbers and plant heights of all identified target species were recorded.

For each site and revegetation approach (direct seeding or planting) we calculated: the resulting woody plant density (plants per hectare); the proportion of species that were either sown or planted which established (i.e. were represented by live individuals at the time of survey); species 
121

122

123

124

125

126

127

128

129

130

131

132

133

134

135

136

137

138

139

140

141

142

143

144

145

146

147

richness, including those species that recruited naturally - species not sown/planted; species diversity, based on Pielou's evenness index (a measure of how evenly individuals are distributed across species; Pielou 1966); and mean plant heights.

At the two sites where seed was broadcast by hand (Hoddles Creek and McMahons Creek), plant density was calculated on a per $\mathrm{m}^{2}$ basis and then scaled up to a per hectare basis. For the remaining sites, plant density in sown lines was calculated on a plants per lineal metre basis and then scaled up assuming 3 linear kilometres of sowing lines per hectare. All plant nomenclature conforms to that of Walsh and Stajsic (2007).

(1)

\section{Results}

Plant density

Direct seeding typically resulted in higher plant densities than planting ( 5 out of 6 cases; Table 2)the latter being largely determined by initial planting density. In some cases, resulting plant densities were an order of magnitude greater in sown than planted areas, e.g. 21,866 plants/ha in broadcast sown plots compared to 2,000 plants/ha in planted plots at Hoddles Creek (Table 2).

Low plant densities resulting from direct seeding at some sites were attributable to environmental factors. For example, dry conditions prevailed following the 2015 direct seeding at Deep Creek. Frosts and low rainfall befell the 2017 sowing at Emu Creek, while at the Sheepstation Creek site waterlogging is likely to have limited plant recruitment from direct seeding. Such conditions also typically hampered the survival or condition of plantings, but to a lesser extent.

\section{Species establishment}

The number of species that established compared to the number sown/planted was generally lower for direct seeding than planting, with a median of $67 \%$ of target species establishing in direct seeded areas compared to $100 \%$ in planted areas (Table 2). Direct seeding did not result in all sown species establishing at any site (maximum $=90 \%$ ). In contrast, in all but one of the eight revegetation projects assessed, $100 \%$ of the planted species established. Notably, that site (Hoddles Creek) was the only one in which the tube-stock plantings were not guarded or fenced.

This article is protected by copyright. All rights reserved 


\section{Species richness}

Even though more species were often included in the sowing mix than were planted at each site (Table 1), the native woody species richness recorded in sown and planted areas were generally similar (Table 2). The two exceptions were: Hoddles Creek, where plantings were unguarded and damaged by browser and human impacts; and McMahons Creek, where despite the very high plant densities resulting from direct seeding $(100,000+$ plants/ha), only 9 of the 17 sown species established (an additional two species Silver Wattle, Acacia dealbata, and Yarra Burgan, Kunzea leptospermoides, naturally recruited within sown areas). Species introductions resulting from natural recruitment were not common and limited (Table 2).

\section{Species diversity (evenness)}

The species diversity (evenness) of plants resulting from direct seeding was consistently lower, and in some cases much lower, than that for plantings (Table 2), with direct seeded areas commonly dominated by one or two (often Acacia) species (Figure 2). For example, at Launching Place, Silver Wattle accounted for 272 out of the 397 plants surveyed (69\% of all plants). In contrast, the dominant species in the planted areas, Swamp Gum (Eucalyptus ovata) and Prickly Moses (A. verticillata), accounted for $13 \%$ and $11 \%$ of plants, respectively. Similarly, at Cardinia Creek, Hedge Wattle (A. paradoxa) and Prickly Moses accounted for $80 \%$ of all plants resulting from direct seeding, and at Emu Creek, four Acacia spp. accounted for $84 \%$ of all plants resulting from the 2017 sowing (13 species sown) (Figure 2).

\section{Plant heights}

Mean plant heights (ignoring some large between-species differences) largely reflected the age of the revegetation, with plants unsurprisingly taller with increased age. There was also a tendency for plants to be taller at sites with wetter climates than at sites with drier climates at a similar age. At the youngest sites, planted plants tended to be taller than direct seeded plants, reflecting the different ages of the plants. However, direct seeded plants were taller than their planted counterparts at the two oldest sites surveyed, Hoddles Creek (4 years) and Launching Place (2.5 years) (Table 2).

Some sites with relatively low plant densities resulting from direct seeding also had relatively low plant heights, often as a result of herbivory. High levels of browsing of both direct seeded plants and plantings was apparent at the Cardinia, Emu, Sheepstation and Deep Creek sites. 
179

180

181

182

183

184

185

186

187

188

189

190

191

192

193

194

195

196

197

198

199

200

201

202

203

204

205

206

207

208

209

210

\section{Discussion}

Our assessments of seven revegetation projects in the first years after establishment suggest that direct seeding tends to result in greater plant density, similar species richness, but lower rates of species establishment and species diversity than planting.

\section{Plant density outcomes}

Our findings are consistent with previous studies that have found that direct seedling typically results in higher plant densities than planting tube-stock (England et al. 2013; Freitas et al. 2019). Also consistent with previous studies, direct seeding outcomes were quite variable between our study sites. Such variability has been highlighted by other reviews of direct seeding outcomes, e.g. 150-8460 plants/ha for 50 sites in northern Victoria (Pryde and Duncan 2015) and 860-20,000 plants/ha for three sites in Tasmania (Close and Davidson 2003). In contrast, densities resulting from planting can be expected to be more predictable (based on initial planting densities).

Stem densities at two of our sites (Hoddles Creek and McMahons Creek) were particularly high $(20,000+$ stems/ha), but were similar to densities found at 1.5 year old direct seeded sites in the Southern Tablelands of NSW ( 17,000 stems/ha; Schneemann and McElhinny 2012). Indeed, plant densities resulting from direct seeding are often much higher than those of the vegetation communities that the revegetation is attempting to restore (Pryde and Duncan 2015; Schneemann and McElhinny 2012). This is potentially of concern given that high stem densities resulting from revegetation can delay the provision of habitat features such as tree hollows and fallen logs by decades (Vesk et al. 2008). However, plant densities resulting from direct seeding can be expected to decline with age (Schneemann and McElhinny 2012), as is commonly seen in natural recruitment events after a disturbance such as a flood or fire.

\section{Species establishment, species richness and diversity outcomes}

Direct seeding typically resulted in much lower proportions of species establishment (compared to the number introduced) than planting. In all projects where plants were guarded, all planted species were represented. In contrast, approximately two-thirds of the sown species established via direct seeding. These proportions of species establishment from direct seeding are comparable to those found in a study in southern Western Australia at similarly aged sites: 15-70\% across eight direct seeding projects (Heydenrych and Ten Seldam 2011).

Nonetheless, because more species were often sown than were planted, the species richness of direct seeded and planted areas were similar, at most sites. However, the diversity (evenness of spread of individuals across species) was typically much lower for direct seeded areas. This lower

This article is protected by copyright. All rights reserved 
211

212

213

214

215

216

217

218

219

220

221

222

223

224

225

226

227

228

229

230

231

232

233

234

235

236

237

238

239

240

241

242

diversity (evenness) of species in the early stages of establishment following direct seeding is of concern given that sown sites are likely to decline in species richness with age (Schneemann and McElhinny 2012). Such declines have been attributed to a few dominant overstorey species (e.g. Acacia species) monopolising site resources (Close and Davidson 2003). Similarly, in our study, one or a few Acacia species often dominated sown areas; these may become more dominant over time, further depressing diversity. Notably, relatively unpalatable Acacia species (e.g. Hedge Wattle at Deep Creek) tended to be particularly dominant at sites where browsing impacts were common and direct seeding resulted in low-moderate stem densities.

It should be noted, however, that our study only assessed relatively young revegetation sites, and analyses of revegetation outcomes over longer time periods may also reveal declining species richness in tube-stock plantings over time, as has been observed at some sites (D. Robertson, personal observation). It is also worth noting that survival of planted specimens does not necessarily mean that progeny of that species will germinate on the site in the future-one of the long-term goals of restoration. In contrast, the potential for germination has already been demonstrated in the case of those species that successfully germinated and established on site from direct seeding.

\section{Plant growth and overall revegetation outcomes}

Direct seeded plants were taller than tube-stock plants at the older ( $>2$ years-old) sites we assessed. This suggests that initial differences in plant heights between tube-stock plants and seedlings resulting from direct seeding may be readily overcome. Moreover, given the higher stem densities in direct sown areas, stand development is likely to be faster for direct seeded than planted areas (England et al. 2013; Freitas et al. 2019).

Nonetheless, at our sites, overall revegetation outcomes were often driven by environmental factors, regardless of revegetation method. Sites that experienced conditions that were particularly dry (e.g. Deep Creek) or wet (Sheepstation Creek) generally had poorer outcomes. Herbivory was another impediment to plant establishment and growth at many of our sites. It is likely that weed competition also limited plant establishment at some sites. These results reflect the findings that climatic factors (e.g. droughts, flooding) and biotic interactions (herbivory and competition) are often major constraints to revegetation efforts globally (Palma and Laurance 2015).

Such constraints are likely to be more deleterious to seedlings that arise from direct seeding than planted tube-stock due the limited ability of young seedlings to compete for resources. It is likely that this greater vulnerability of small seedlings to the vagaries of weather, herbivores and competition make direct seeding outcomes so variable (Close and Davidson 2003; Pryde and Duncan 
2015). While direct seeding is cheaper than planting, planting seedlings can yield better results in terms of increased survivorship, potentially accelerating recovery of vegetation structure and diversity (Palma and Laurance 2015).

\section{Potential strategies for enhancing revegetation outcomes}

Revegetation is undertaken for many reasons, in riparian areas these tend to be for biodiversity, erosion control or water quality purposes. If high species diversity is not a primary objective, direct seeding is likely to be the most cost-effective approach, given appropriate management of weeds, browsing threats and abiotic limitations, where possible. Where higher species richness is needed, supplementary planting may be beneficial.

Regardless of revegetation approach (direct seeding or planting), in drier environments contingencies should be made for the potential need to water young plants (Close and Davidson 2003). A good understanding of browsing pressures at a site is necessary to guide appropriate browser protection measures, while appropriate pre- and post-revegetation weed control is also critical (Close and Davidson 2003).

Where biodiversity gains are the primary aim of the revegetation, it is possible that a combined approach including both sowing and planting may prove most fruitful. Hardier or more reliable species may be sown, combined with planting and guarding of more palatable or keystone or rare species (Jusaitis and Polomka 2008). Alternatively, Schneemann and McElhinny (2012) suggest tubestock planting of overstorey species and direct seeding of mid- and understorey species to minimise competition, achieve appropriate stem densities and maximise species diversity. Some authors and practitioners suggest a successional approach, with sowing and planting occurring in stages to facilitate appropriate structural development and enhance diversity (Close and Davidson 2003; Cole et al. 2011).

There is good evidence to suggest using a greater number of species in sowing mixes increases the species richness of direct seeding outcomes (Kirmer et al. 2012; Pryde and Duncan 2015; Schneemann and McElhinny 2012). Although using species-rich species mixes is more expensive, resultant diversity gains are likely to improve vegetation community development (Kirmer et al. 2012; Palma and Laurance 2015). Species selection for revegetation is often constrained by availability (Palma and Laurance 2015), and in Australia, there is a need to better develop our seed production industries (Cuneo et al. 2018). Importantly, species selection for direct seeding is often less constrained than for planting (Palma and Laurance 2015) - as was found in our study with greater numbers of species used in direct seeding than planting. 
We suggest that when diverse native vegetation communities are the goal, optimal revegetation outcomes are likely to be achieved when direct seeding and planting are used in tandem.

\section{References}

Ammondt SA, Litton CM, Ellsworth LM and Leary JK (2013) Restoration of native plant communities in a Hawaiian dry lowland ecosystem dominated by the invasive grass Megathyrsus maximus.

Applied Vegetation Science 16, 29-39.

Atondo-Bueno EJ, Bonilla-Moheno M and López-Barrera F (2018) Cost-efficiency analysis of seedling introduction vs. direct seeding of Oreomunnea mexicana for secondary forest enrichment. Forest Ecology and Management 409, 399-406.

Benayas JMR, Newton AC, Diaz A and Bullock JM (2009) Enhancement of biodiversity and ecosystem services by ecological restoration: a meta-analysis. Science 325, 1121-1124.

Brooks SS and Lake PS (2007) River restoration in Victoria, Australia: change is in the wind, and none too soon. Restoration Ecology 15, 584-591.

Close DC and Davidson NJ (2003) Revegetation to combat tree decline in the Midlands and Derwent Valley Lowlands of Tasmania: Practices for improved plant establishment. Ecological Management \& Restoration 4, 29-36.

Cole RJ, Holl KD, Keene C and Zahawi RA (2011) Direct seeding of late-successional trees to restore tropical montane forest. Forest Ecology and Management 261, 1590-1597.

Cuneo P, Gibson-Roy P, Fifield G, Broadhurst L, Berryman T, Crawford A and Freudenberger D (2018) Restoring grassy woodland diversity through direct seeding: Insights from six 'best-practice' case studies in southern Australia. Ecological Management \& Restoration 19, 124-135.

This article is protected by copyright. All rights reserved 
304

305

306

307

308

309

310

311

312

313

314

315

316

317

318

319

320

321

322

323

324

325

326

327

328

329

330

331

332

Ede FJ, Greet J, Dabal R and Robertson D Counting the cost of revegetation: is direct seeding cheaper than planting tube-stock? In 'Restore, Regenerate, Revegetate: A Conference on Restoring Ecological Processes, Ecosystems and Landscapes in a Changing World ', 2017, Armidale, NSW, Australia. (Ed. R Smith), pp. 29-30

England JR, Franks EJ, Weston CJ and Polglase PJ (2013) Early growth of environmental plantings in relation to site and management factors. Ecological Management \& Restoration 14, 25-31.

Freitas MG, Rodrigues SB, Campos-Filho EM, do Carmo GHP, da Veiga JM, Junqueira RGP and Vieira DLM (2019) Evaluating the success of direct seeding for tropical forest restoration over ten years. Forest Ecology and Management 438, 224-232.

Heydenrych B and Ten Seldam D (2011) A preliminary evaluation of native plant establishment by direct seeding at a range of sites on the south coast of Western Australia. Greening Australia, Western Australia.

Jusaitis M and Polomka L (2008) Weeds and propagule type influence translocation success in the endangered Whibley Wattle, Acacia whibleyana (Leguminosae: Mimosoideae). Ecological

Management \& Restoration 9, 72-76.

Kirmer A, Baasch A and Tischew S (2012) Sowing of low and high diversity seed mixtures in ecological restoration of surface mined-land. Applied Vegetation Science 15, 198-207.

Palma AC and Laurance SGW (2015) A review of the use of direct seeding and seedling plantings in restoration: what do we know and where should we go? Applied Vegetation Science 18, 561-568.

Pérez DR, González F, Ceballos C, Oneto ME and Aronson J (2019) Direct seeding and outplantings in drylands of Argentinean Patagonia: estimated costs, and prospects for large-scale restoration and rehabilitation. Restoration Ecology, https://doi.org/10.1111/rec.12961. 
334

336

337

338

339

340

341

Pielou EC (1966) Species-diversity and pattern-diversity in the study of ecological succession. Journal of Theoretical Biology 10, 370-383.

Pryde EC and Duncan DH (2015) Monitoring and assessment of direct seeding revegetation projects in the Goulburn Broken CMA. A report to the Goulburn Broken Catcment Management Authority. School of Biosciences, University of Melbourne.

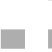

Ruiz-Jaen MC and Mitchell Aide T (2005) Restoration success: how is it being measured? Restoration Ecology 13, 569-577.

Ruthrof KX, Douglas TK, Calver MC, Barber PA, Dell B and Hardy GESJ (2010) Restoration treatments improve seedling establishment in a degraded Mediterranean-type Eucalyptus ecosystem. Australian Journal of Botany 58, 646-655.

Schneemann B and McElhinny C (2012) Shrubby today but not tomorrow? Structure, composition and regeneration dynamics of direct seeded revegetation. Ecological Management \& Restoration 13, 282-289.

Vesk PA, Nolan R, Thomson JR, Dorrough JW and MacNally R (2008) Time lags in provision of habitat resources through revegetation. Biological Conservation 141, 174-186.

Walsh NG and Stajsic V (2007) 'A Census of the vascular plants of Victoria ' Eighth Edition edn. (Royal Botanic Gardens: Melbourne, Australia).

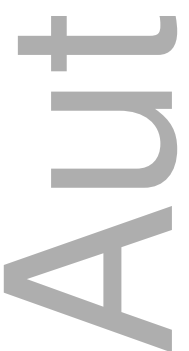

This article is protected by copyright. All rights reserved 
Table 1: Study site and revegetation details, including weed control and other site preparation/maintenance details, and age at assessment. MAR = Mean annual rainfall, taken from nearest Bureau of Meteorology station.

\begin{tabular}{|c|c|c|c|c|c|}
\hline 0 & Description & $\begin{array}{l}\text { Sowing/Planting (no. } \\
\text { species sown/planted) }\end{array}$ & Site maintenance & Plant protection & $\begin{array}{l}\text { Age at assessment } \\
\text { ( years) }\end{array}$ \\
\hline Hoddles Creek & $\begin{array}{l}\text { Riparian crown land } \\
60 \times 1200 \mathrm{~m} \\
\text { Some remnant vegetation } \\
\text { nearby } \\
\text { MAR: } 884 \mathrm{~mm}\end{array}$ & $\begin{array}{l}5 \text { plots each } 100 \mathrm{~m}^{2} \\
\text { containing } 40-50 \text { niches } \\
\text { Niches either hand sown } \\
\text { (3 plots) or planted with } \\
1 \text { plant per niche ( } 2 \text { plots) } \\
\text { (20/7 trees and shrubs) }\end{array}$ & $\begin{array}{l}\text { Weed control at } 1 \text { and } 3 \\
\text { months after } \\
\text { establishment }\end{array}$ & $\begin{array}{l}\text { Unfenced } \\
\text { Tube-stock unguarded, } \\
\text { jute mats installed }\end{array}$ & 4 \\
\hline $\begin{array}{l}\text { Launching Place } \\
\text { (Yarra River) }\end{array}$ & $\begin{array}{l}\text { Ex-pasture } \\
4 \mathrm{~km} \text { stream frontage, } \\
\text { varying width } \\
\text { Limited remnant } \\
\text { vegetation nearby } \\
\text { MAR: } 884 \mathrm{~mm}\end{array}$ & $\begin{array}{l}6.2 \mathrm{~km} \text { lines direct seeded } \\
\text { (mechanical) } \\
6,000 \text { tube-stock plants } \\
\text { (18/13 trees and shrubs) }\end{array}$ & $\begin{array}{l}\text { Seeding line edges } \\
\text { sprayed } 1 \text { and } 2 \text { months } \\
\text { after sowing }\end{array}$ & $\begin{array}{l}\text { Unfenced } \\
\text { Tube-stock guarded } \\
\text { with plastic guards, jute } \\
\text { mats installed }\end{array}$ & 2.5 \\
\hline Cardinia Creek & $\begin{array}{l}\text { Retarding basin } \\
\text { Approximately } 1 \text { ha }\end{array}$ & $\begin{array}{l}104 \mathrm{~m} \text { lines direct seeded } \\
\text { (mechanical) }\end{array}$ & $\begin{array}{l}\text { Seeding line edges } \\
\text { sprayed 1, } 2 \text { and } 3\end{array}$ & $\begin{array}{l}\text { Unfenced } \\
\text { Tube-stock guarded }\end{array}$ & 2 \\
\hline
\end{tabular}

This article is protected by copyright. All rights reserved 


\begin{tabular}{|c|c|c|c|c|c|}
\hline & $\begin{array}{l}\text { Limited remnant } \\
\text { vegetation nearby }\end{array}$ & $\begin{array}{l}288 \text { tube-stock plants } \\
\text { (6/6 shrubs) }\end{array}$ & $\begin{array}{l}\text { months after sowing, } \\
\text { then } 3 x / \text { year }\end{array}$ & $\begin{array}{l}\text { with plastic guards, jute } \\
\text { mats installed }\end{array}$ & \\
\hline 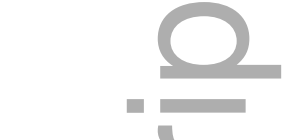 & MAR: $936 \mathrm{~mm}$ & & $\begin{array}{l}\text { Tube-stock sprayed } \\
3 x / \text { year }\end{array}$ & & \\
\hline $\begin{array}{l}\text { McMahons Creek } \\
\text { (Yarra River) }\end{array}$ & $\begin{array}{l}\text { Ex-pasture } \\
70 \times 800 \mathrm{~m} \\
\text { National Park adjacent } \\
\text { MAR: } 1380 \mathrm{~mm}\end{array}$ & $\begin{array}{l}13 \text { plots each } 225 \mathrm{~m}^{2} \\
\text { Plots either hand sown (4 } \\
\text { plots) or planted with } \\
350 \text { tube-stock ( } 9 \text { plots) } \\
\text { (17/23 trees and shrubs) }\end{array}$ & $\begin{array}{l}\text { Sprayed at 1, } 4 \text { and } 5 \\
\text { months after sowing }\end{array}$ & $\begin{array}{l}\text { Fenced with deer and } \\
\text { rabbit proof fences } \\
\text { Tube-stock had jute } \\
\text { mats installed }\end{array}$ & 2 \\
\hline Emu Creek & $\begin{array}{l}\text { Ex-agriculture, quarry } \\
\text { adjacent } \\
\text { Approximately } 1.5 \text { ha } \\
\text { Very limited remnant } \\
\text { vegetation nearby } \\
\text { MAR: } 587 \mathrm{~mm}\end{array}$ & $\begin{array}{l}800 \text { m lines direct seeded } \\
\text { (mechanical), both years } \\
\text { 2016: } 400 \text { plants; } 2017: \\
264 \text { plants } \\
\text { (2016: } 17 / 14 \text { trees and } \\
\text { shrubs; } 2017: 13 / 8 \text { trees } \\
\text { and shrubs) }\end{array}$ & $\begin{array}{l}\text { Slashing/spraying } \\
\text { between lines } 2 x \text { yearly } \\
\text { Watering ( } 2-3 x / \text { summer) } \\
\text { On-going rabbit control }\end{array}$ & $\begin{array}{l}\text { Unfenced } \\
\text { Tube-stock guarded } \\
\text { with wire guards }\end{array}$ & $\begin{array}{l}2,1 \text { (revegetation } \\
\text { across two years) }\end{array}$ \\
\hline $\begin{array}{l}\text { Sheepstation } \\
\text { Creek }\end{array}$ & $\begin{array}{l}\text { Ex-pasture } \\
0.5 \text { ha }\end{array}$ & $\begin{array}{l}\text { Site direct seeded } \\
\text { (mechanical) in lines }\end{array}$ & $\begin{array}{l}\text { Seeding line edges } \\
\text { sprayed }\end{array}$ & $\begin{array}{l}\text { Unfenced } \\
\text { Tube-stock guarded }\end{array}$ & 1.5 \\
\hline
\end{tabular}

This article is protected by copyright. All rights reserved 


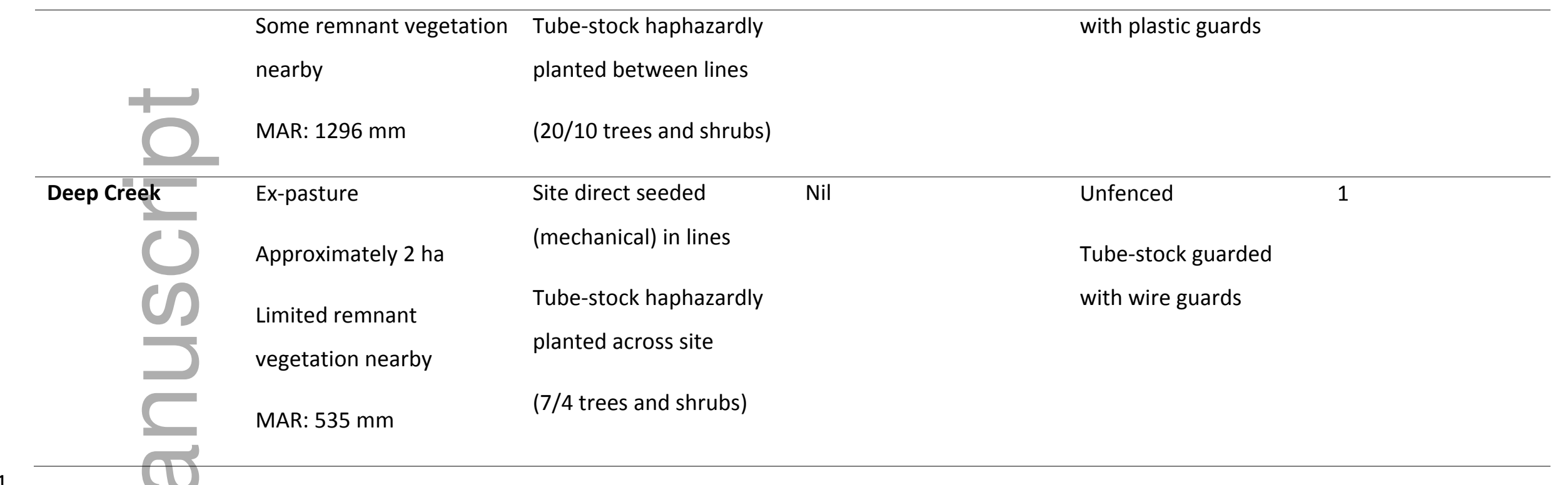

Table 2. Plant densities, species establishment, species richness, species diversity (evenness) and heights of plants established by either direct seeding or planting at seven sites between

one and four years after revegetation (see Table 1 for details). $n=$ total number of plants sampled; NA - not applicable.

\begin{tabular}{|c|c|c|c|c|c|c|c|c|c|c|c|c|}
\hline \multirow[t]{2}{*}{ Site } & \multicolumn{2}{|c|}{$n$} & \multicolumn{2}{|c|}{$\begin{array}{l}\text { Plant density } \\
\text { (plants/ha) }\end{array}$} & \multicolumn{2}{|c|}{$\begin{array}{c}\text { Species } \\
\text { establishment }\end{array}$} & \multicolumn{2}{|c|}{$\begin{array}{c}\text { Species } \\
\text { richness* }\end{array}$} & \multicolumn{2}{|c|}{$\begin{array}{c}\text { Species diversity } \\
\text { (evenness) }\end{array}$} & \multicolumn{2}{|c|}{$\begin{array}{l}\text { Plant heights } \\
\text { (cm } \pm \mathrm{SE})\end{array}$} \\
\hline & Sown & Planted & Sown & Planted & Sown & Planted & Sown & Planted & Sown & Planted & Sown & Planted \\
\hline Hoddles Creek & 719 & 40 & 21,866 & 2,000 & $90 \%$ & $57 \%$ & 18 & $7(3)$ & 0.65 & 0.88 & $200 \pm 5$ & $143 \pm 15$ \\
\hline Launching Place & 397 & 373 & 1,985 & 1,193 & $61 \%$ & $100 \%$ & $12(1)$ & $17(4)$ & 0.48 & 0.93 & $406 \pm 16$ & $387 \pm 16$ \\
\hline Cardinia Creek & 69 & 226 & 2,019 & 6,519 & $83 \%$ & $100 \%$ & 5 & 6 & 0.66 & 0.93 & $73 \pm 5$ & $138 \pm 4$ \\
\hline McMahons Creek & 366 & 236 & 103,300 & 14,067 & $53 \%$ & $100 \%$ & $11(2)$ & 23 & 0.73 & 0.94 & $153 \pm 4$ & $257 \pm 11$ \\
\hline Emu Creek & & & & & & & & & & & & \\
\hline
\end{tabular}

This article is protected by copyright. All rights reserved 


\begin{tabular}{|c|c|c|c|c|c|c|c|c|c|c|c|c|}
\hline 2016 & 661 & 332 & 2,486 & 1,252 & $71 \%$ & $100 \%$ & $13(1)$ & 14 & 0.73 & 0.96 & $29 \pm 1$ & $90 \pm 3$ \\
\hline 2017 & 436 & 221 & 1,654 & 829 & $62 \%$ & $100 \%$ & 8 & 8 & 0.81 & 0.96 & $13 \pm 1$ & $40 \pm 1$ \\
\hline Sheepstation Creek & 243 & 50 & 806 & NA & $50 \%$ & $100 \%$ & 10 & 10 & 0.90 & 0.92 & $18 \pm 1$ & $32 \pm 2$ \\
\hline Deep Creek & 70 & 50 & 700 & NA & $71 \%$ & $100 \%$ & 5 & $5(1)$ & 0.67 & 0.85 & $9 \pm 1$ & $31 \pm 2$ \\
\hline Median & 382 & 224 & 2,002 & 1,626 & $67 \%$ & $100 \%$ & 10.5 & 9 & 0.70 & 0.93 & 51 & 90 \\
\hline
\end{tabular}

*Numbers of species recorded that were not sown/planted, i.e. natural recruits, shown in parentheses.

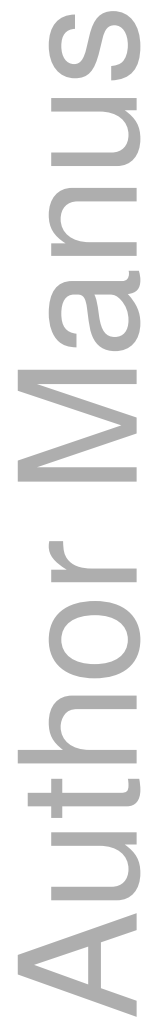

This article is protected by copyright. All rights reserved 

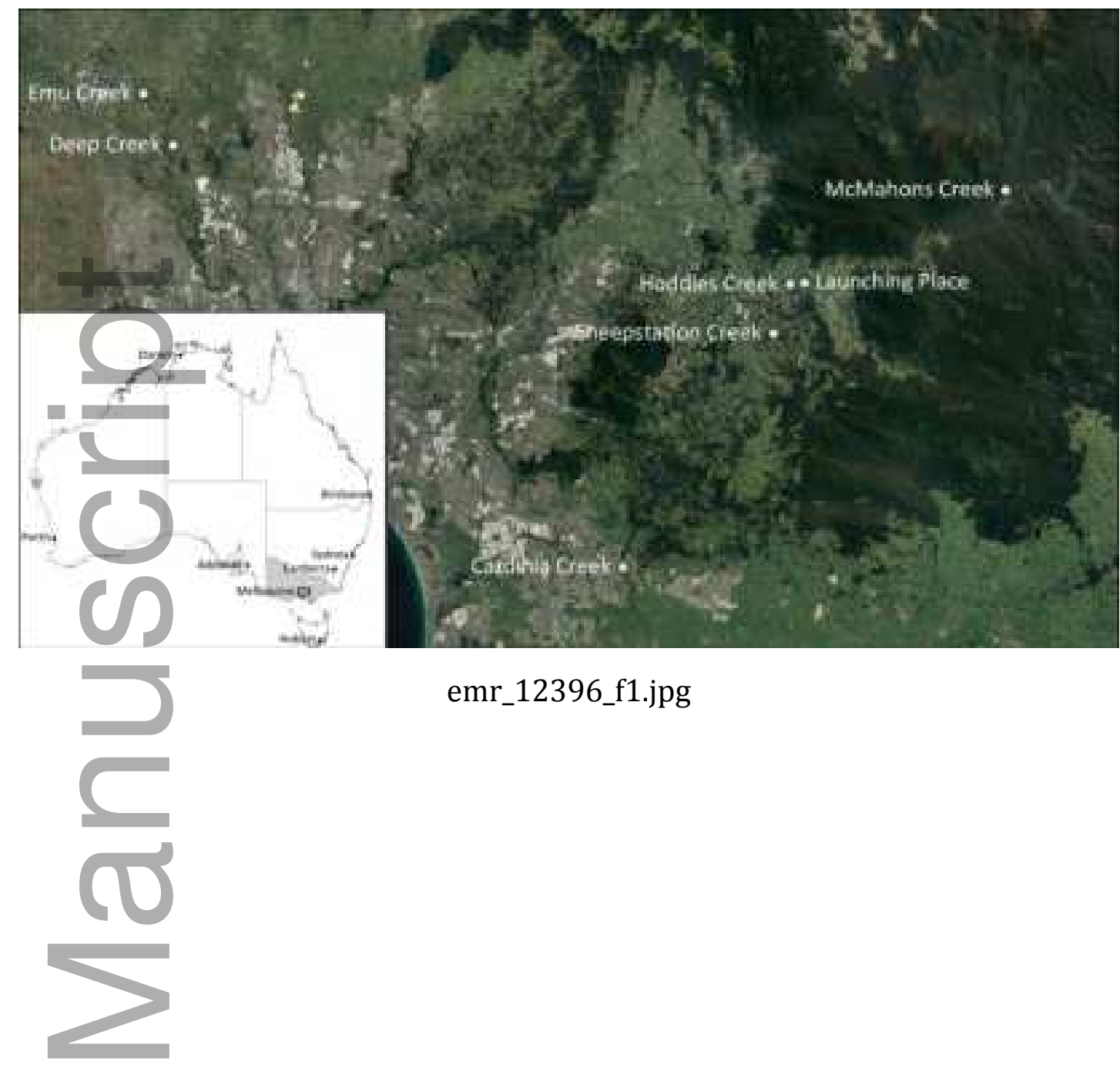

emr_12396_f1.jpg

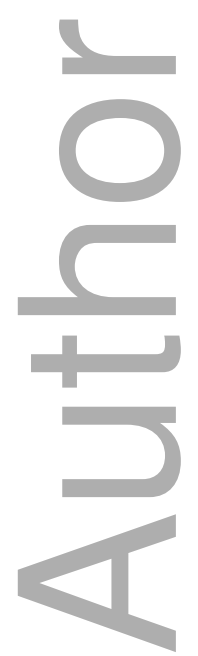




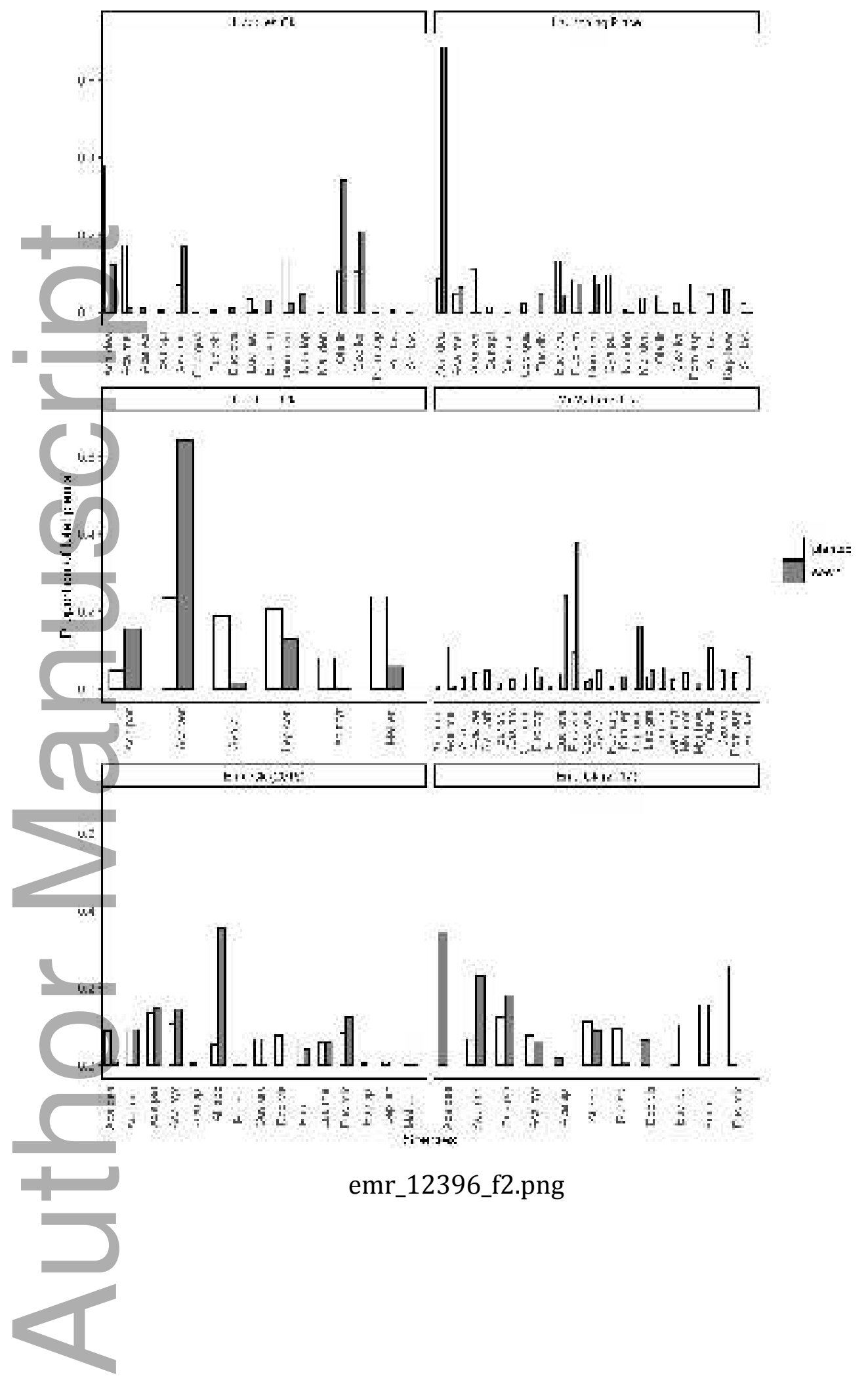

This article is protected by copyright. All rights reserved 


\section{University Library}

\section{- M M N E R VA A gateway to Melbourne's research publications}

Minerva Access is the Institutional Repository of The University of Melbourne

\section{Author/s:}

Greet, J;Ede, F;Robertson, D;McKendrick, S

Title:

Should I plant or should I sow? Restoration outcomes compared across seven riparian revegetation projects

\section{Date:}

2019-12-20

\section{Citation:}

Greet, J., Ede, F., Robertson, D. \& McKendrick, S. (2019). Should I plant or should I sow? Restoration outcomes compared across seven riparian revegetation projects. ECOLOGICAL MANAGEMENT \& RESTORATION, 21 (1), pp.58-65. https://doi.org/10.1111/emr.12396.

Persistent Link:

http://hdl.handle.net/11343/286767 